\title{
J. Swanepoel
}

Departement Latyn

\section{STAAT ER WAT ER STAAT? \\ RESEPSIES VAN GATULLUS SE CARMEN XLIX}

\section{INLEIDING}

Gaius Valerius Catullus (c. 84-c. 54 v.C.), die Romeinse digter wat veral bekend is vir sy verse aan sy geliefde Lesbia, het benewens liefdesgedigte ook 'n hele aantal verse geskryf waarin van sy tydgenote figureer. Hierdie gedigte wat aan spesifieke persone gerig is, is wyd uiteenlopend en dic toon en strekking daarvan wissel van toegeneentheid en liefde enersyds (vgl. Carmen IX) tot felle invektief (Carmina CVIII, XCIII) en spot (Carmen LXXXIV) andersyds. Die leser kan gewoonlik maklik vasstel of hy in 'n gedig met vriend of vyand te doen het. Maar daar is een uitsondering, en dit is Catullus se gedig aan die Romeinse staatsman, retor en skrywer, Marcus Tullius Cicero. Hierdie gedig, wat soos die meeste van Catullus se gedigte heel kort en kragtig is, is deur die eeue op uitcenlopende en botsende wyses geïnterpreteer. Enersyds word dit beskou as 'n opregte dankbetuiging en lofprysing aan Cicero, terwyl ander lesers dit weer sien as 'n gedig wat ironies bedoel is.

Aangcsien die resepsies van hierdie gedig so uiteenlopend is, en die een interpretasie die ander logieserwys uitsluit, moet daar in die eerste plek gevra word op grond van watter onderliggende aannames, literatuurbeskouing, beskikbare getuienis en bewysvoering daar tot sulke teenstrydige lesings van dieselfde gedig gekom word.

Voortvloeiend hieruit moet die vraag ook gestel word watter van hierdie botsende interpretasies die beste verantwoord en dus die waarskynlikste is. Of is die gedig op so 'n manier geformuleer dat daar'n saak vir albei die lesings uigenaak kan word?

Hierdie vraagstuk vest ig die aandag prominent op die rol en funksie wat die leser in die ontsluiting en interpretasie van 'n literère teks vervul. Dit laat die vraag ontstaan in watter mate die betekenis van 'n literêre teks in die teks self gespesifiseer is. Of is dit so dat 'n leser redelik willekcurig 'n beteken is aan 'n teks kan oplê? Is bloot dit wat in 'n gestruktureerde teks gesê word genoegsaam vir die verstaan daarvan? (Of is sekere buite-tekstuele inligting onontbeerlik vir insig daarin? Is die betekenis van 'n literêre werk a-histories en tydloos? Speel die leser se kennis van die werklikheid, sy vertroudheid 
met die literatuur, sy literatuurbeskouing en verwagtingspatroon 'n deurslaggewende rol in sy interpretasie van die gedig? Of lê die waarheid êrens tussenin? So kan dic vrae vermenigvuldig word.

In die bespreking sal van die standpunt uitgegaan word dat enige interpretasie van 'n teks slegs ' $n$ voorstel is, al is dit dan ' $n$ beredeneerde voorstel.

Ek sal in die artikel probeer aantoon hoe die argumente ten gunste van elk van die interpretasies van Catullus se gedig opgebou is. Daar sal ook gepoog word om aan te toon watter literatuurbeskouing daaraan ten grondslag lề en watter konsekwensies dit inhou vir die leser se omgaan met die teks.

\section{BEGRIPPEAPPARAAT}

\subsection{Ironie}

Aangesien die begrip ironie sentraal staan in hierdie dispuut, moet daar kortliks stilgestaan word by die aard, soorte, tipiese tegnieke en funksies van ironie.

Die teksboekdefinisie van ironie dateer rceds uit die klassieke retoriese teorie, nl. dat ironie daarin bestaan dat 'n spreker/skrywer een ding sê terwyl hy iets anders (dikwels die teenoorgestelde daarvan) bedoel. As sodanig is dit verwant aan sarkasme, maar tog onderskeie daarvan, aangesien ironie gewoonlik subtieler is, terwyl sarkasme direk en maklik herkenbaar is. In sarkasme kan dit wat gesê word onmoontlik dit wees wat bedoel word, terwyl die hoorder/lescr van 'n stuk ironie soms sal twyfel of werklik gesê word wat bedoel word en of gesê word wat juis nié bedocl word nie. Alhoewel ironie gewoonlik subtieler te werk gaan as sarkasme is die elfek daarvan dikwels des te skerper.

Liberman en Foster (1968:63) toon aan dat die standaarddefinisic hierbo nie alle manifestasies van ironie dek nie, en dat dit nuttiger is om ironie te beskou as die bestaan van 'n sekere tweede perspektief op 'n taaluiting of handeling waarvan die leser bewus gemaak word.

Daar is dan ook verskillende soorte ironie waarvan nie almal verbaal is nie. So onderskei van Gorp (1980:84-85) tussen sokratiese ironie, verbale ironie, situasionele (of dramatiese) ironie en romantiese ironie.

Een van die metodes waardeur verbale ironie bewerkstellig word, is dat woorde uit hul normale konteks gelig word, waardeur hulle dan 'n ander 
betekenis kry as wat die oppervlakuiting laat vermoed. Daar is dus 'n sekere "ambigue kwaliteit" (Van Gorp: 1980:84) in die taaluiting.

Situasionele ironic bcrus op ' $\mathrm{n}$ meerkennis by die leser. Hy kan byvoorbeeld van mcer bewus wees as die persoon aan wie 'n ironiese uiting gerig is of as die een deur wie dit gemaak word.

Onder romantiese ironic word verstaan dat 'n spreker/outeur homself bewustelik relativeer, iets wat duidelik word uit 'n bewuste ironiese spreek-/skryflouding.

Die leser herken 'n taaluit ing as ironies op grond van 'n dubbelsinnigheid in dic taalstruktuur van die boodskap, of op grond van die feit dat dit wat gesê word nie klop met dit wat die hoorder/leser weet aangaande die situasie waarop die taaluiting betrekking het nie.

Ironic is gewoonlik 'n wapen in die hand van 'n satiris, maar ook dramaturge maak graag daarvan gebruik. Twee van die standaardtegnieke van dic ironikus is hiperbool ('n oordrewe en aangedikte stelwyse) en sy teenhanger meiosis of onderbetoning waar juis minder gesê word as wat bedoel word.

Ironic kan vele funksies vervul. Om met Cuddon (1979:339) te praat: "It is often the witting or unwitting instrument of truth. It chides, purifies, refines, deflates, scorns, and 'sends up' ".

\subsection{Teksbeskouing}

Voorstanders van dic Resepsie-estetika, veral Hans Robert Jauss, het aangetoon dat die literatuur deur die loop van die eeue vir lesers om verskillende redes ge ïnteresseer het en dat literêre tekste deur die lens van verskillende teoretiese "brille" of paradigmas bestudeer is. Ook in die wetenskapsteorie word die belangrikheid ingesien van die paradigma waarbinne die wetenskaplike werk. Die wetenskapshistorikus T.S. Kuhn se werk "The Structure of scientific revolutions" (1962) het die aandag baie prominent hierop gevestig.

Die resepsies van Catullus se gedig wat in hierdie artikel bespreek word, datecr uit die negentiende en twintigste ccu. Daarom is dit belangrik om na te gaan hoe die literatuur in hierdie tydperk benader is. Drie benaderingswyses kan onderskei word, te wete 'n beskouing van die literêre teks as dokument, as monument en as tekensisteem (kyk Van Coller, 1983). Hierdie benaderingswyses kan natuurlik nie waterdig van mekaar afgeskei word in 
tydperke nie, aangesien sommige navorsers steeds kan voortwerk binne 'n ou paradigma, selfs wannecr 'n nuwe paradigma dic hecrsende geword het. Maar 'n ruwe veralgemening kan gemaak word. Onder dic invloed van die positivisme kry ons sedert die tweede helfe van die negentiende ecu 'n belangstelling in die teks as dokument van òl die skrywer òf die tydsomstandighede (sosiaal, polities, intellcktueel, ckonomics, ens.) waaruit dit ontstaan het. Dic teks eis nic sosecr die aandag vir homself op nie; dit gaan cintlik om wat "agter" of buite die teks lêे, waaroor die literêre werk iets wil sê. Dikwels is die verband tussen hierdic agterliggende faktore (of dit nou dic psige van die skrywer of sekere fasette van die tydsgewrig is) en die literêre werk as 'n kousale verband gesien: dit veroorsaak die spesilicke teks, en omgekeerd - dic teks is weer belangrik omdat dit vir dic leser iets sê oor die causae.

Sedert dic vrorë twintigste ceu tot en met die sestiger-/sewentigerjare kry ons 'n belangstelling in die teks as monument. Die fokus is nou op die teks as teks, soms met 'n groot premic op die sg. outonomic daarvan. Dic New Critics, Russiese Formaliste en die voorstanders van die werkimmanente Interpretation was die vernaamste eksponente van hierdic benadering. Dit gaan in hierdic skole veral om dit wat literatiteit konstitueer, om die uit wysing van die organisasic van die taalmiddele in 'n literêre teks tot 'n samehangende geheel en die bewysvoering is hoofsaaklik intratekstuecl.

Sedert die jare sestig is daar 'n belangstelling in die teks as semioticse sistecm, met groot klcm op dic leser se aktualiscring van clic tekens in 'n teks, maar waarby ook die hele kommunikasiesituasie in berckening gebring word. Hicr word ook gegewens oor dic skrywer, die sosiale en literêre konteks waarbinne 'n werk ontstaan, maar veral oor die leser met sy waardesisteme en verwagtingshorison in berckening gebring, alhocwel dit op 'n gesolistikecrder wyse as in die oucrc kousalistiese teorieë geskied.

Ek sal in die verdere bespreking probecr aantoon dat dic voorstanders van 'n nie-ironiese interpretasic van Catullus se gedig die werk primêr benader as dokument. Aan die ander kant kan die argumente van diegene wat 'n ironicse lesing voorstaan (selfs al is dit nic eksplisiet so gedoen nie) ingeorden word binne die raamwerk van 'n benadering van dic teks as 'n gest rukturcerde tekensistecm wat deur die leser geaktualisecr word. Alhoewel die teks ook in hierclie benadering in 'n sckere sin dokument is van iets buite die gedig, gaan dit eerder om dic lcesavontuur as om die agterliggende situasie.

\subsection{Bewysplase}

In die analise van die argumente ten gunste van elk van die interpretasies, 
sal onderskei word tussen intratekstuele, intertekstuele en kontekstuele getuienis.

Intratcksthele getuien is is die getuienis wat aangevoer word met 'n beroep slegs op die teiks.

Die beroep op intertekstucle getuienis gaan uit van die veronderstelling dat geen teks insulêr is nie, nıaar rlat dit gesitueer is tussen ancier rekste. Hier ag ek dit norlig om 'n onderskeid te tref tussen intertekstuele getuienis uit werke van dieselfde outcur (in cusu. uit die res van die oeuvre van Catullus) en intertekstucle gctuicuis ut! die werke van ander outeurs, bv. dic van tydgenoutlike skrywers.

Onder kuntekstuele getuienis sal hicr daardie getuienis verstaan word wat die ravorser betrek op grond van sy kennis van dic tydvak waarin die gedig ontstaan hei, maar wat nie in soveel woorde in ' $n$ teks uitgespel is nie, inaar berus op rekunstruksie en xonjektuur.

\section{CATULLUS SE GEDIG FN 'N VERTALING DAAKVAN}

\subsection{Catullus se gedig:}

\section{Carmen $X ! . I X$}

1. Disertissime Romuli nepotum,

2. quot sunt quotque furte, Marce Tull:,

3. quotque post alis crunt in annis,

4. gratias tibi maximas Ciatullus

5. agit pessimus omnium pocta,

6. tanto pessimus urrinium pocta

\%. quarito iu optimus omnium patronus.

\subsection{Letterlike vertaling daarvan}

Ter wille daarvan dat dicgene wat Latyn nie magtig is nie dic latere argunentasıe kan volg, en ondat partv van die argumeite gebaseer is op die spesitieke taalvorme wat in die gedig gehruik wort, probcer ek nic om hicr 'i, dinanirs $c k$ wivalente vertaling te bied nic, maar'n vertaling wat uiters lellerlik en woord vir woord te werk gaan. Die resullaat vatu so'n verialing is uitcraard stram cu onpö̈ntes. 
1. Welsprekendste van dic kleinscuns van Romulus,

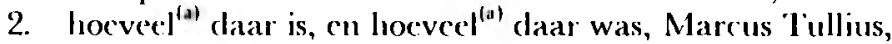

3. cn hocvecl ${ }^{(1.1)}$ daar later in ander jare sal bestaan/wees,

4. dic allergrootstc lank betuig Catullus

5. aan jou, (hy) die allerslegste digter van almal,

6. (hy wat) in so 'n mate die allerslegste digter (is) van almal

7. as wat jy dic heel beste advokaat van $/ \mathrm{vir}^{(\text {h) }}$ almal (is).

Die volgende opmerkings is ter sake:

(a) Die Latynse woorde "quot" en "quotque" is hier vertaal met "hocverl" en "en hocvecl". 'n Minder stram vertaling sou wees:

"sovecl as wat daar is, ch sovecl as wat daar was, Marcus Tullius, en sovecl as wat daar later in ander jare sal wees"

(b) Dic grammatikale konstruksic "optimus omnium patronus" kan in batyn twee betekenisse liĉ (1) "dlic beste advokaat uan almal" of (2) "dlic beste advokaat/pleitbesorger vir almal" (kyk 5.3.2).

(c) Gedecltes tussen hakies is ter wille van duidelikheid in die Afrikaanse vertaling ingevoeg.

\section{VERSORGANISASIE}

Die vraag mag onwillekeurig by dic leser van hierdie artikel opkom of die botsende interpretasies van hierdie gedig dalk nic dic gevolg daarvan is dat dic outeur dit wat hy wou sê nic duidelik geformulecr het nic. Om aan te toon dat dit nie dic geval is nic, sal die aandag kortliks gevestig word op sckere fasette van die strukt urcring van dic gedig - dit wil sê clie organisasic van taalmiddele in die vers - wat so'n opvat ling baic on waarskynlik maak. Dic hoolkleon sal hier nic primêr op semantiese fasettc val nie (hoewel dit ook betrek word) maar op sintaktiesc en loniese organisasieprinsipes.

Die gedig bestaan uit slegs cen sin, wat in scwe versreëls ont plooi word, en wel met 'n sekere ordening. Versrec̈ls een tot drie is 'n uitgebreide aanspreking van Ciccro. Versrec̈ls twee en dric vorm 'n kleiner cenheid binne hierdie aanspreking, $c n$ wel as uitbreiding tot wat in die ecrste versreêl gesê is. Dit word sintakties gemarkeer deur die herhaling van "quot" (2), "quotque" (2) en "quotque" (3). Eweneens is versreëls eeu en twee aan mekaar verbonde. Dit geskied deur die plasing van dic vokaticl "Disertissime" in dic aanvangsposisic in versrël cen, wat gebalansecr 
word deur die apostroof "Marce 'l'ulli" (uiteraard eweneens in die vokatief) in die cinclposisic van verssecl twee. Algesien van luul posisie in die vers is daar ook foniesc verwantskap) (ussen ecrs- en laasgenocmole woorde.

Ons kan dit skematies so voorstel:

1. Disertissime Romuli nepotum,

2. quot sunt quotque fuere, Marce Tulli

2. quotque post aliis crunt in annis,

Daarna volg die hoolsin as middelstuk waar rondom dic res van dic gedig gerangskik is:

4. gratias tibi maximas Catullus

5a agit

Dit word opgevolg deur twee versreäls wat nog strenger herhalingsgedecltes beval as versteds iwee en drie

51) ... pessimus omnium pocta,

6 lanto pessimus omnium porta

Die I weede, derde en vierde wourde is ident ies, en ons het dus te make met sintaktiese koppeling, as uithreiding op dic sinsonderwerp "Catullus" (4), en wel deur apposisie. Dit is analoog aan die uilbreiding van versteël een deur twee en dric.

Lin net soos verstëls een en twee sintakties en lonies in verband gehring is deur die vokillewe, net so is versiects ses en sewe gekoppel deur die korclaticwe "tanto" (6) en "quanto" (7) in aanvangsposisics.

Waar die frases "pessimus ommium poeta" in (5) cn (6) semant ies, sintakties en Ionie's identies is, daar word hierdie woorde min die kortelatiewe tanto ... quamo in opposisic gestel tor "optimus ommium patronus" in (7). Die semantiese opposisie lussen "pessimus" en "optimus", word verder ge intensiverer cleurdat daar van "in identiese sintaktiese ordening geloruik 
gemaak word, waarin daar wecr eens sterk foniesc ooreenkomste aan te wys is.

Skcmatics lyk dit dan so:

$$
\text { pessimus omnium poeta }
$$

lanto pessinus omnium pocta

quanto tII

'n Verdere betrekking van opposisies binne dicselfde klankveld is die herhaling van "tu" in "Tulli" (2), "Calullus" (4) en " $u$ " (7).

Om dic klankorganisasic in hicrdie gedig volledig te ekspliseer sou te veel ruimte beslaan. Die leser kan gerus let op die herhaling van die " $t$ ", " $s$ " en " $i$ " in elke versreël, en hiermee is daar nog lank nie uitgepraat oor die klankorganisasic nic.

Wat wel duidelik behoort te wees, is dat ons hier met' $n$ streng georganisecrde vers te doen het - en dit met die behoud van cenvoud en onopgesmuktheid. Juis die deurgekomponeerdheid van die vers maak die botsende interpretasies daarvan des te opvallender, aangesien die digter dit wat hy sê op baie geordende wyse doen.

\section{RESEPSIES VAN CARMEN XLIX}

5.1 As ons dic term van dic 'Tsjeggiese Strukturalis, Jan Mukarovský, gebruik, kan gesê word dat Gatullus se Carmen XL.IX as artefakt - as dit wat deur dic kunstenaar tot stand gebring is, as tekens op papier - identies is vir alle ondersockers.

Maar interpretasie veronderstel noodwendig ' $n$ kensubjek en dit is ' $n$ historiese feit dat verskillende lesers se aktualisering van hicrdie artefakt tot estetiese objck in die resepsiegeskiedenis daarvan nie identies verloop het nic.

Teoretiese besinning oor dic rol van dic leser in die ontsluiting van die literêre werk het in die twintigste ceu al 'n hele aantal lesers opgelewer, bv. 
die geïmpliseerde leser, die ideale leser, die "informed reader" ens. Teenoor hierdie abstrakte leser staan die werklike of reële leser, en dit is aan die opgetckende rescpsies van hierdie lesers waarin daar in die volgende onderafdeling (5.2) aandag geskenk sal word. In die daaropvolgende onderafdelings (5.3) sal daar ook gebruik gemaak word van resepsies van reële lesers, maar die net sal daar wyer gespan word om ook 'n abstrakter leser te betrek, n.a.v. die moontlikhede wat die teks bied.

\subsection{Er staat wat er staat}

Vir lesers wat Catullus se gedig as 'n opregte dankbetuiging of gratiarum actio beskou, is dic gedig eenvoudig en die interpretasic daarvan voor-die-handliggend. Die leser moet cenvoudig net lees wat daar staan en dit op sigwaarde aanvaar.

Die gedig word deur voorstanders van hierdie interpretasie primêr gesien as iets wat verwys na 'n wêreld buite die gedig, of te wel die sogenaande ekstralinguale werklikheid. En - so kan tekstueel aangetoon word met 'n berocp op die oorwegings wat in paragraaf vier genocm is - die dankbetuiging is vol eenvoud en helderheid verpak.

Die gedig noem tog duidelik vir Catullus en Marcus Tullius op die naam. En as die praenomen en nomen nie genoeg is om die persoon na wie met die woorde "Marce Tulli" verwys word met Cicero te identifiseer - iets wat in elk geval te betwylel is - dan stcl die eerste versreël: "Welsprekendste van die kleinseuns van Romulus" dic identilikasie bo enige twyfel vas. "Marce Tulli" is niemand anders as die historiese figuur, Marcus 'Tullius Cicero, een van die (of selfs dié) begaafdste van Romeinse retors. En, sover dit die dankbetuiging aangaan, daar staan tog uitdruklik "... gratias tibi maximas Catullus/agit" (4-5).

Trouens, die gedig as weerspiec̈ling van Catullus se dank en erkentlikheid werk deurgaans met superlaticwe. Cicero word aangespreek as die welsprekendste van alle Romeine, en dit sluit nie alleen die verlede en die hede in nie, maar ook die toekoms. En wat meer is: "Catullus' prophecy proved true" (Williamson 1969:104). Voorts betuig Catullus "gratias maximas" (4) en is Cicero eksplisict die "optimus" ... patronus" (7). Dic leit dat Catullus twee maal ietwat onvleiend na homself as "hessimus omnium poeta" verwys, is òl te wyte aan opregte nederigheid, òf dit is 'n stukkie speelse humor, òf dit plaas by wyse van kontras Cicero se uitnemendheid in reliêf.

As daar cnigiets is wat verdere aandag vereis of as daar enige onduidelikheid is wat opgeklaar moet word, dan is dit die opdieping van die ontstaansrede 
vir hierdic gedig, en dit is juis op hierdic punt dat kommentatore wat reken "dal er staal wat er staal" hul decglike (hoewel gevaricerde) historiese speurwerk en vindingrykheid ten toon stel. Hulle poog om die rede vir die bedanking op te diep. Sou so 'n rede met stelligheid gerekonstrucer kon word, dan is dit tersclfdertyd stawing vir 'n nie-ironiese interpretasie.

My uiteensetting van hierdie hipotese berus op Fordyce (1965:213-214) se samevatting daarvan. Vir ons doel is nie die gegewens as sodanig belangrik nie, maar dic eksplisering van die metode waarvolgens intertekstuele en kontekstuele getuienis aangewend word in hierdie bewysvoering.

As die teks dan primêr as dokument benader word, is 'n historiese interesse te verwagte. Waarop ' $n$ mens minder voorbereid is, is die uiteenlopendheid van dic hipoteses wat uit die beskikbare (en geselektcerde!) gegewens opgebou word.

\subsection{1* Hipotese 1, variant 1}

Schwabe is van mening dat Catullus Cicero bedank omdat laasgenoemde vir Caclius suksesvol verdedig het teen 'n aanklag wat $\mathrm{L}$. Sempronius Atratinus op aanstigting van Clodia teen hom ingebring het. Clodia was die (eertydse) beminde van Catullus. Gicero word nou bedank omdat hy in hierdie geding vir Clodia uitgewys het vir wat sy werklik is.

Hierdie hipotese berus ten minste op die volgende aannames:

1. Die Lesbia van Catullus se gedigte moet geïdent ifiscer word met Clodia Pulcher, die dogter van Appius Clodius Pulcher en suster van die berugte tribuun en aartsvyand van Cicero, P. Clodius Pulcher. Dat Lesbia die skuilnaam was vir 'n Clodia berus op die getuienis van Apuleius (Apologia 10). Dat Lesbia geïdentifiseer moet word met hierdie spesificke Clodia berus op 'n recks ander argumente wat in Fordyce (1965:xiv-xvi) nagelees kan word. Die meeste kommentatore is van mening dat alhoewel hierdie identifikasie nie as bewese beskou behoort te word nic dit in elk geval nie bots met beskikl)are getuienis nie en daarom redelik waarskynlik is.

2. Dit berus voorts op die veel meer problematiesc identifikasie van Caelius met $M$. Caelius Rufus. Hierdie identifikasie is gegrond op moeilik met mekaar rymbare intertekstuele getuienis (kyk Fordyce, 1965:xv-xvi).

Dit is duidelik dat selfs al sou beide hierdie aannames korrek wees die 
navorser steeds 'n sprong moet maak vanaf hierdie gegewens tot die verknoping daarvan aan Catullus se gedig.

\section{$5.2 .2 *$ Hipotese 1, variant 2}

Baehrens bring die gedig eweneens in verband met Clodia se hofsaak teen Caelius en Cicero se optrede as advokaat in die geding. Hy raflineer die hipotese verder deur te stel dat Cicero bedank word omdat hy Catullus se naam uit die hofsaak gehou het.

\section{$5.2 .3 *$ Hipntese 2}

Westphal maak 'n heel ander historiese rekonstruksie en wel op grond van intertekstuele getuienis van ander outeurs (Plutarchos, Cic. 29; Cicero: Ad Familiares v. 2.6). Hieruit blyk dit dat Cicero in 62 v.C. vir Clodia besoek het toe haar man, Metellus Celer, in Galliê was. Op grond hiervan spekuleer hy dat Cicero bedank word omdat hy Catullus in Clodia se vriendekring voorgestel het.

Die argument berus op die reeds vermelde identifikasie van Lesbia met Clodia Pulcher asook op intertekstuele getuienis van ander outeurs en 'n stuk konjektuur.

\subsubsection{Hipotese 3}

Kroll is op sy beurt van mening dat Catullus Cicero bedank vir een van sy toesprake, waarskynlik die In V'atinium van 56 v.C., wat hy aan Catullus gestuur het.

5.2.5 Soos Fordyce (1965:214) droogweg opmerk: "These theories, some wilder than others, are only guesswork, and guesses can be multiplied". Hy is van mening dat dit nutteloos is om sulke hipoteses te stel, omdat ons nie kennis dra van die persoonlike verhouding tussen Catullus en Cicero nie.

5.2.6 Vir ons doel is dit belangrik om op die volgende sake te let.

1. Daar word deur hierdie kommentatore aangencem dat hul rekonstruksie van die omstandighede wat aanleiding gegee het tot die skryf van die gedig vir die leser nuttig is om die gedig te verstaan. $\Lambda$ s dit dan 'n bedankingsgedig is, dan weet die nou danksy die "historische Forschung" glashelder waarom Catullus Gicero met soveel oorgawe bedank.

2. Dit is ook duidelik dat die opdieping van gegewens uit die werke van 
dieselfde en ander outeurs nie noodwendig vir die navorsers lei tot 'n enkelduidige verklaring van die ontstaanrede en daarmee ook van dic teks nie. Die uiteenlopendheid van die hipoteses hierbo is klinkklare bewys daarvan. Terwyl nie betwis word dat 'n teks tussen ander tekste en ook in 'n sekere konteks gesitucer is nie, is dit ook duidelik dat die rekonstruering van 'n konteks afhanklik is van die bcskikbare gegewens wat opgeteken is, van die interpreteerder se seleksie van die gegewens wat hy as relevant beskou en ook van sy ordening daarvan tot 'n argument. Om 'n teks bloot op grond van 'n rekonstruksie van sodanige agterliggende faktore uit te lê, lyk na 'n gevaarlike spel.

\subsection{Er staat niet wat er staat}

5.3.1 Maar nie alle lesers is tevrede met die interpretasie hierbo nie, en mense soos Wölflin en Schmidt beskou dit as 'n ironiese gedig. Ek sal vervolgens die vernaamste argumente ten gunste van hierdie interpretasie uiteensit; en in die loop van hierdie uiteensetting probeer aantoon dat 'n ander benadering tot die literatuur/literêre werk hieraan ten grondslag lê.

5.3.2 Sommige van die voorstanders van hierdie interpretasie gaan delf ook na 'n ontstaansrede, maar hierdie soektog word van stapel laat loop op grond van 'n dubbelsinnigheid in die teks. Daar word daarop gewys dat die slotwoorde van die gedig "optimus omnium patronus" ambivalent is en dat dit in die standaardgebruik van Latyn kan beteken of 1) "die beste advokaat van almal (d.w.s. van alle advokate) of 2) die beste advokaat/pleitbesorger vir almal. Die "omnium" word hiervolgens nie neutraal opgeneem as bloot "vir almal" nie, maar as "vir 'n ieder en 'n elk", "vir Jan Rap en sy maat" of op Engels "for all and sundry".

Die sintaktiese parallelisme tussen "pessimus omnium poeta" (5 en 6) en "optimus omnium patronus" laat dit by 'n eerste lees voorkom asof die eerste lesing in hierdie omgewing die toepaslike een is, maar op grond van ander sleutels of wenke in die gedig (kyk 5.3) kan 'n sterk saak vir die tweede lesing uitgemaak word. As "optimus omnium patronus" dan beteken "beste advokaat vir Jan Rap en sy maat" dan gaan soek party van die voorstanders van 'n ironiese interpretasie na so 'n situasie in Cicero se loopbaan. En wie soek sal vind, al is dit dan weer eens spekulatief.

Die hipotese sien so daaruit: Ciccro het in 54 v.C. vir Vatinus, ' $n$ berugte karakter, suksesvol verdedig teen 'n aanklag van Calvus, Catullus se mededigter en vriend. Dit het Catullus aanstoot gegec en daarom sou 'n klag van "indiscriminate advocacy" dan gereguerdigd wees, en steun dit nie alleen op 'n dubbelsinnigheid in die sintaksis van die gedig nie, maar is die 
situasie waarop dit betrekking het dan ook uitgewys.

Dit is belangrik om daarop te let dat selfs as "optimus omnium patronus" die betekenis van "die beste advokaat van almal" het, dic uitdrukking steeds ironies kan wees. Dan berus die ironie nie op 'n dubbelsinnigheid in die sintaksis nie, maar op die diskrepansie tussen wat op die oppervlak gesê word en wat bedoel word. Die "optimus omnium partronus" verteenwoordig dan net so min die werklike toedrag van sake as die betiteling van Catullus se "pessimus omnium poeta".

5.3.3 'n Ander rede vir die ironisering in Catallus se gedig word gesoek in Cicero se geringskatting van Catullus se poësie. Dit is goed bekend dat Cicero nie 'n bewonderaar was van die avant-garde digters, die sg. "novi poelae", waarvan Catullus een van die hooffigure was nie. Die bewysplase hiervoor kan gevind word in Cicero se brief aan sy vriend Atticus (Cicero, Ad Atticum VII) asook in sy filosofiese geskrif, die Tusculanae Disputationes (III, 45). Hier verwys Cicero nie baie vleiend na hierdie nuwe digters nie. Voorts is dit ook bekend dat Cicero 'n bewonderaar was van die ou digters, die "establishment"-skrywers soos Quintus Ennius, en hy het ook self in sy eie werk hierdic ouer tradisie voortgesit.

Op die oog af lyk hierdie hipotese dus redelik oortuigend, maar ook hier is daar 'n problecm, aangesien hierdie twee geskrifte van Cicero eers na die dood van Catullus geskryf is. Maar 'n teenargument is moontlik, naamlik dat dit nie uitgesluit kan word dat Cicero as 'n redelike uitgesproke man en as 'n prominente figuur in die literêre wêreld van sy tyd sy opinie oor die "novi poetae" reeds vroeër mondelings te kenne gegee het voordat hy dit later op skrif gestel het. Dit is inderdaad moontlik, maar eweneens is dit geen bewese feit nie.

Al raak die argument asie ook in hierdie geval die wêreld agter die gedig, is daar weer 'n aanknopingspunt met 'n tekstuele gegewe, naamlik met die ironies bedoelde teenstelling tussen "pessimus omnium poeta" (5 en 6) en "optimus omnium patronus" (7).

Dit is egter duidelik in die volgende argumente waar strenger met tekstuele gegewens omgegaan word waarin ' $n$ ander literatuurbenadering duideliker blyk.

\subsubsection{Die aanspreekvorm}

5.3.4. I Die aanspreking van Cicero beslaan drie van die totaal van sewe versreëls van die gedig. Dit is gelaai met gloeiende superlatiewe. Dit wil dus voorkom asof ons hier met ' $n$ hiperboliese stelwyse te docn het, en soos reeds opgemerk is, is hiperbool een van die mees algemene tegnieke om ironie te bewerkstellig. 


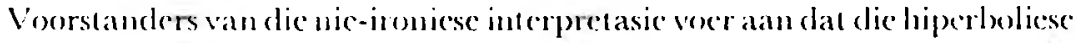
aanspreckvorm nic muxampas is nie as in ag gencenn word dal (atultus, 'n jong diger, hom hicr rig to 'n vername persoon in dic Romeinse samelewing "u litcrêre "estalbishment".

Matar as die volgende getuienis ook in berekening geloring word, lyk die skaal beslis geswati in die rigling van 'n ironiese interprelasie.

5.3.4.2 Die versteal "Disertissime Romuli nefutum" rocp intertekstued in assosiasie op met (allullus se (armen I,VIII, watal "magnanimi Remi nepoles" kemelik ironies gclmuik is. Fordyce (1965:321) nocm dit dan ook "n "quasiepie grandiose phrase".

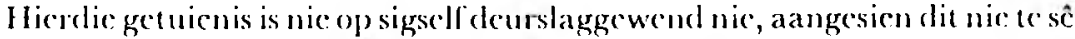
is dal twee gelyksoontige frases in alsonderlike gedigte nood wendig diesclfite funksic of semanticse ladling dra nic, veral nie as cecu gedig ' $n$ ironisering van (/dankloctuiging aan) 'n retor is, en die ander 'n wilbedeling van dic degradasic van 'n (ecris) gelicfde is nic.

5.3.4.3 Catullus en die ander nori poetae neig baie tot die gewone sprecktaal, tol dit wat Quim "the language of conversation improved upon" of sermo purus nocm (1979):155). Dit is minter hoogdtawend as die mecer bewusiclik "poüı iese" cn oratoriese taalgel)ruik van liul voorgangers. Bime die konteks van Calullus se oruvre vertecnwoordig dit beslis '" afwy king, nie net van sy cic standaardgeloruik nie, maar ook van 'n litercre konvensic van die nuwe digters.

5.3.4.4 Voorts getuig Catullus se poësic van 'n a-masionale ingesteldheid, ( $n$ is 'n vaderlandse liase soos "Diserlissime Remmuli nepolum" baie skaars in sy gedligte, en dit in ternstelling tol die praktyk van sowel sy voorgangers as latere Romeinse digners (kyk Williamson, 1969: 10$)$.

5.3.4.5 Die gedagte dat iemand sy tydgenote, voorgangers en diegene wat later sal kom oortrel (vergelyk versirëls $2 \mathrm{cn} 3$ ) $\mathrm{kom}$ ook in dic geskrifte van ander Roneinse skrywers voor.

So vind ons by die komedieskrywer Plautus (Persa 777) die woorde "tuisuml

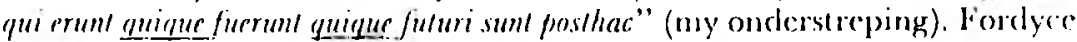
(1965:215) nocm dil tereg "mock solemn extravagance". ()ok in dic werk van (icero word hicedie gedage verwoord, byvoorleceld as hy vir Pompeius

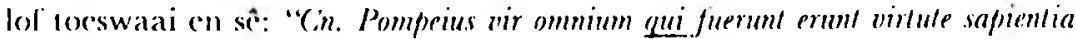
gloria princeps" (post Red. acl Quir. 16). Ook in sy bricwe (Ad Familiares XI, 21, 1) tref ons 'n soortgelyke frase aan, die keer as 'n beswadtering: 
“... nequissimo ommium qui sumt qui fuerumt qui futuri sum" (onderstreping van my).

Die onderstrecpte woorde qui en quique in die sitate hierbo verteenwoordig die normale en mees algemene gebruik van die relalicwe voornaamwoord in sodianige Latynse sinne. Maar in plaas van qui en quique skryf (atullus clie minder gebruiklike (hoewcl nie ongranımatikale) quot en quotque. So word daar m.i. 'n hiperboliese elfek bewerkstellig, en dit in 'n recels hiperboliese aanspreckwyse.

5.3.4.6 Die aanspreckvorm "Mnre 'Tulli" hied 'n verdere interpretatiewe leiclraad, aangesien so 'n aanspreckvorm "the ceremonial style of address used in the Senate" (Fordyce, 1965:215) verteenwoordlig. As sodanig sluit dil aan by die vernaamdocnerigheid van die res van die cerste dric versrë̈ls.

Dit is ook moontlik dat hierdie aanspreckvorm 'n subteks oprorp naamlik die woorde wat (Gicero in die mond van die staat lè: "si omnis res publica sie loquatur: "Marce Tulli, quid ayis."' (In Catilinam 1,27). Cicero laat hom hier op 'n baic formele wyse aanspreck. Catullus gebruik die identiese vorm, maar met ironiserende effek, cnersyds vanwë̈ die graad van formalitcit en andersyds (indien dit inderdaad 'n toespeling op (iicero se woorde is) vanweë die spanning tussen teks en subteks.

5.3.4.7 Sommige outeurs beskou dic betiteling van ('icero as 'n kleinseun van Romulus (I) as 'n sarkast iese toespeling op (icero se provinsiale alkoms, maar (lit is onwaarskynlik in die lig van die leit dat Cicero homsell dikwels op sy provinsiale alkoms beroem het. As verder in gedagte gelou word dat ook Catullus nie 'n gebore Romein was maar ewencens uit dic provinsies gekom leet lyk die argument nie baic oortuigend nie (Fordyce 1965:214-215).

5.3.4.8 Die woord "disertissimu" het gewoonlik 'n baie positicwe konnotasic. Ellis (1876:135) vestig egter dic aandag op sekere passasies waar "disertus" in tecnstelling tot "ploquens" gebruik word. "n Retor wat diser/us is beskik oor tegniese vaardigheid, terwyl een wat eloquens is nie net tegnies gord is nie, maar 'n natuurlike aanleg vir die we'sprekendheidskuns het. Fillis (1876: 135) toon egter ook ann dat hierelie wontre in ander omgewings sinoniem gebruik word en daarom lyk dit nie vir my of "disettissime" in die ecrste versreël om hicrdie spesilieke rede as ironies opgencem behoort te word nie. Dit is egter moont lik dat dit om 'n ander rede'n steck in die rigting van (Cicero mag wees (kyk par. 6).

5.3.5 Catullus se verwysing na homself (en dit in die verwyderde derde persoon) as "pessimms ommum poeta" is "a humility so cxaggerated as hardly to 
escape the suspicion of persillage" (Villis 1876:135). Uit Cattullus se ocuve is dic duidelik clat hy, allonewel liy soms sy skrylwerk iromiseer (Carmen 1.4), 'n bate sellbewuste digere is. I)ic kontrapunt van clie ironiese "pessmmus anmium poefa" (wat boonop nog hertial word) is "oprimus mmium palromus" (7). Dic vraag is net of Catullus se sellironisering noolwendig onk beteken dat "optimus ommium patromes" ironies bedocl word. 1)it lyk vir my waarskynlik en wel op groud van dic verbinding van hicrdie twec lases deur tanto ... quanto (kyk egter liondyce 1965:214).

5.3 .6()$_{p}$ dic dubbelsinnighcid van "optimus ommium patronus" is recels ingegaan (kyk 5.3.2). Al wat hicraan torgevoeg moct word is clat dic digter deur die sintakt iese parallelisme l ussen versue bos lei, totclat hy die rlubbelsimngheid van verseël sewe insicu. Lin juis die feit dat claar van ooreconstemmende sintakticse ordening gebruik gemaak word om 'n teenstelling te markecr, verhoog die trelkrag daarvan.

5.3.7 Dic argumentasiestrategie ten gunste van hierdic lesing sicn dus sons volg claaruit: as die gedig ironies is, moet icts auders bedocl word as wat op) dic oppervlak gesê word. ()m so 'n lesing te regverdig, moet sckere sleutels tot in nie-voor-die-hand-liggende interpretasic gesock word. lin dit word dan primôr gesock in dic toks, in 'n vergelyking van dic toks met tersaaklike tekste en (in 'n mindere mate) ook in die teks se verhouding tot die wêrełd luite die teks.

1)aar word gewys op ambivalensics in die leks asook op die bomulting van stylmidricle (veral hiperbool) wat tipies is an ironic. 1)aar word ook intertekstucle argumente: aangevoer, veral net betrekking tot die alwyking van sekere literêre konvensies. Waar claar gepoog word oun die wêreld agter dic teks to rekonstuneer, geskied dit of) grond van spesilicke tekstuele: gegewens. Kortom: daar is in hierdie benadering 'n groter klem op die bewustelike benutting van taal cu sy moontlikluede. 1)ic gedig word in ' sckere sin beskou as 'n soort legkant: dic leser moct kyk hoc die verskillende' stukke daarvan in nekaar steck en 'n patroon daaran mak. Allocwel nic al clie argunente: wat hierbo genocm is op sigsell genone ewe oortuigend is nie, is die konstellasie daarvan en die feit dat hulle nekaar komplementecr ch aanvul 'n belangrike oorweging ten gunste van hicrelic interpretasie. Dic teks is dus nie bleot die dokument van 'n historiese gegewe nie, maar is icts wat die leser se andatg ope is ook en sells primồ vir die lekensisteem sell. 1) ie' benaderingswyse en argumentasiestrategic is meer literề as die bruadering wat angetref word by die voorstanders van 'n nie-ironiese interpretasie wat veral geinteressecerd is in clic rekonst ruksic van dic geskiedenis agter dic teks. 


\section{KONKLUSIE}

Aangesien ironic dikwels subticl te werk gaan, hoef dit 'n mens nie te verbaas dat hicrdic teks op twee uitcculopende wyses uitgelê word nic. Die gedig is op sy minste ambivalent, maal op grond van dic leserswenke in die teks lyk 'n ironiese interpretasie vir my dic waarskynlikste. So 'n interpretasic is ook as leeservaring bociender. Myns insiens word nie net Cicero nie, maar ook die leser se been getrek. Die gedig is ook in dic opsig ironies dat dic spreker wat lomself ctikettecr as die slegste digter van almal en hom in reliëf stel tot die uiterste welsprekende retor dit op 'n wyse doen wat sell uiters 'disertus' is. Kortom: "he is beating him at his own game".

Hoc dit ookal sy, die uitecnsetting hierbo laat duidelik blyk hoe 'n belangrike rol die leser en die paradigma waardeur hy die literêre werk benader in dic aktualisering van dic gedig speel. Maar eweneens is die gedig ook nie sonder meer "n "oop plan" waarmce dic leser na willekcur kan omgaan nic. En hicr lê die knoop: in die estcticse crvaring (asook in en die wetenskaplike verantwoording (laarvan) is daar nic net 'n leser/kensubjek nic, ook nie net 'n objek wat sonder meer sy betekenis mecleel nic. Daar word in dic lecshandeling 'n brug gebou tussen die kensubjek met sy tcoretiese raanwerk, sy heuristiese en hermeneutiese vermoc̈ en die objek met sy struktuur, of - as dit 'n te groot woord is - sy wegwysers en aanduidings vir die aktualisering daarvan.

\section{BIBLIOGRAFIE}

GUDDON, J.A. 1979. A Dictionary of literary terms. André Deutsch, I,ondon.

FLLIS, R. 1876. $\Lambda$ Commentary on Catullus. Claredon Press, Oxford.

FORIYYCL, C.J. 1965. Catullus. Clarendon Press, Oxford.

KUHN, IT.S. 1962. The Structure of scientific revolutions. 2nd ed. enl. University of Chicago Press, Chicago.

I.IBLEMAN, M.M. \& FOS'TER, E.F. 1968. A Modern lexicon of literary tcrms. Scott, Foresman and Company. Glennview, Illinois.

QUINN, K. 1979. 'I'xts and contexts. The roman writers and their audience. Routeledge \& Kegan Paul; London, Boston and Henley.

VAN C.OL.L.ER, H.P. 1983. Tcoretiese benaderings van dic letterkunde in die jarc tagtig. Literator, 4(3): Potchefstroom.

VAN (GORP, H. (red.) 1980. Lexicon van literaire termen. Wolters, Noordholr Groningen.

WIL,IAMSON, G.A. 1969. Pocms of Catullus. Bell, London. 